scribed, or the transcriptions are being corrected, at the present time. The following is a list of these interviews, which should be available by January, 1991: Vincent R. Browne, James M. Burns, Gwendolyn Carter,
Robert A. Dahl, David Easton, Leon Epstein, Heinz Eulau, Marian Irish, Robert Martin, Warren Miller, Louise Overaker, William Riker, John Turner, Vernon Van Dyke, and John Wahlke.

\title{
NEH Projects Dealing with Women and Politics Themes*
}

\author{
Kenneth Kolson, Deputy to the Director, Division of \\ Education Programs, National Endowment for the Humanities
}

I.

\section{Overview of the NEH**}

In order to "promote progress and scholarship in the humanities and the arts in the United States," Congress passed the National :oundation on the Arts and Humanities Act of 1965. This act established the National Endowment for the Humanities as an independent grantmaking agency of the federal government to support research, education, and public programs in the humanities. Grants are made through five divisions-Education Programs, Fellowships and Seminars, General Programs, Research Programs, and State Programs, and two offices, the Office of Challenge Grants and the Office of Preservation.

The staff of these divisions and offices guide applications through a peer review process to recommend projects for funding. The final responsibility for awards rests by law with the Chairman of the Endowment, who is appointed for a fouryear term by the President of the United States, with the advice and consent of the Senate. The Chairman is advised by the National Council on the Humanities, twenty-six distinguished private citizens who are also nominated by the President and confirmed by the Senate.

\section{The Humanities}

In the act that established the National Endowment for the Humanities, the term humanities includes, but is not limited to, the study of the following disciplines: history; philosophy; languages; linguistics; literature; archaeology; jurisprudence; the history, theory, and criticism of the arts; ethics; comparative religion; and those aspects of the social sciences that employ historical or philosophical approaches.

\section{What the Endowment Supports}

The National Endowment for the Humanities supports exemplary work to advance and disseminate knowledge in all the disciplines of the humanities. Endowment support is intended to complement and assist private and local efforts and to serve as a catalyst to increase nonfederal support for projects of high quality.

Although the activities funded by the Endowment vary greatly in cost, in the numbers of people involved, and in their specific intents and benefits, they all have in common two requirements for funding: significance to learning in the humanities and excellence in conception.

\section{How Applications Are Evaluated}

Generally, each application submitted to Endowment programs is assessed by knowledgeable persons outside the Endowment who are asked for their judgments about the quality of the proposed project. Nearly 1,000 scholars and professionals in the humanities serve on approximately 150 panels throughout the course of a year. The judgment of panelists is often supplemented by individual reviews solicited from specialists who have extensive knowledge of the specific subject area dealt with in the application. The Endowment receives approximately 8,000
When additional interviews have been completed and transcribed, information about their availability will be released, approximately once a year, in $P S$. applications each year, of which about 2,800 are funded. Our annual budget is in the neighborhood of $\$ 150$ million, of which only about $15 \%$ is spent on administration.

\section{Special Initiatives}

The Foundations of American Society. Within its existing programs, the Endowment has encouraged study, research, and discussion about the history, culture, and principles of the foundation period, an emphasis that began with the NEH initiative on the bicentennial of the U.S. Constitution. Proposals may deal directly with the events and achievements of the founding period, including the ratification of the Constitution, the establishment of the federal government, and the works of philosophy, politics, literature, and art that were produced during the founding period. They may also treat later events, achievements, and works that have resulted or developed from the founding period or that reflect or respond to its concerns and principles.

The Columbian Quincentenary. As part of the international observance of the 500th anniversary of Christopher Columbus's voyage of discovery to the New World, NEH invites proposals for original scholarship on related topics and for the dissemination of both new and existing scholarship. Topics may include the expansion of European civilization through the efforts of the Spanish and Portuguese crowns and the establishment of new societies and new forms of cultural expression through encounters among native American, European, and African 
peoples. Proposals may also explore the ideas-political, religious, philosophical, scientific, technological, and aesthetic-that shaped the processes of exploration, settlement, and cultural conflict and transformation set into motion by Columbus's momentous voyage.

It is important to note that applications responding to special initiatives are not sequestered for review, that is, they are not reviewed separately or against special criteria. Nor are these applications privileged in any way. Thus, applicants are well advised not to turn their projects inside out in order to relate them to an NEH initiative.

\section{II.}

\section{The NEH and Political Science}

Because the NEH (unlike, for example, NSF) organizes its work according to purpose and audiencerather than by discipline-prospective applicants should be guided by the nature of their project when requesting guidelines and application materials. For example, a political scientist seeking time off from teaching to prepare a scholarly manuscript for publication should probably look to the Division of Fellowships and Seminars for support. Political scientists wishing to hold a conference on some aspect of women and politics research would approach the Division of Research Programs. Any kind of curricular project or, say, a summer institute on the Bill of Rights for high school social studies teachers would be brought to the Division of Education Programs. Any member of the Endowment staff can help prospective applicants match their projects with the appropriate program officer.

Political scientists should proceed with caution, however. While the Endowment's purview extends to the social sciences, our activities are confined to those projects that are essentially historical or philosophical. Political philosophy has always received generous support from the Endowment. Illustrative grants might include those awarded to Wilson Carey McWilliams of Rutgers University in support of various projects on the U.S. Constitution and the topic of religion and politics. Richard Flathman of The Johns Hopkins
University has led a summer seminar on "Political Freedom," and David L. Schaefer of Holy Cross has directed several summer institutes for schoolteachers on "Polis and Res Publica." Arlene Saxonhouse of the University of Michigan received funding for a fellowship project entitled "Unity and Diversity in Greek Political Thought." Michael Gillespie of Duke University received support for "The Origins and Meaning of Nihilism." That the National Endowment for the Humanities should put a premium on political philosophy reflects the origins of our discipline as well as legislative intent, but one might argue that there is also some rough justice in it, considering that political philosophers are less likely to be supported by other sources to which political scientists naturally turn-the National Science Foundation, for example-for funding.

In addition to political philosophy, jurisprudence, which is specifically mentioned in our enabling legislation, has also served as a gate through which many political scientists (e.g., Joel Grossman of the University of Wisconsin, Walter Murphy of Princeton University, or Henry Abraham of the University of Virginia) pass. Even in this area, however, explicit efforts by applicants to connect proposal topics to enduring humanities themes or texts are to be encouraged. Proposals on public law and jurisprudence topics sometimes are less persuasive than they need to be because their narratives immerse the reader in case law prematurely-that is, without first showing that the topic at handnamely, the meaning of justice-has concerned humanities scholars continuously since the time of Socrates.

Many political scientists, including those whose professional reputations have been based on empirical, analytical scholarship, have found that they can best render their projects competitive at the NEH by adopting the approach of political history. In recent summers, for instance, college teacher seminars have been offered by Sidney Tarrow of Cornell University ("Historical Studies of Collective Action and Political Change") and by Stephen $T$. Holmes of the University of
Chicago ("Origins and Development of European Liberalism"). In 1989, Bernard Brown of the City University of New York offered a summer seminar, in situ, on "Modern French Politics." Daniel Elazar of Temple University has offered summer institutes designed for elementary and secondary school teachers on the subject of federalism. For some of the political scientists participating in these projects, the appeal of these topics might well have lain primarily in their contemporary significance. But ahistorical grant proposals from political scientists are not ordinarily competitive at the NEH. Each of the projects listed above was successful as an NEH grant proposal in large part because the historical dimensions of the topic under consideration were fully explicated in the proposal narrative.

Many other "mainstream" political scientists have had their work supported by the Endowment. For example, the Endowment has supported some of the research that Fred I. Greenstein of Princeton University has conducted on leadership in the modern American presidency. Russell Hardin of the University of Chicago is heading a collaborative research project that compares democratic institutions throughout the world. Aaron Wildavsky of the University of California, Berkeley, has offered a summer seminar on "Political Cultures." The Endowment is not even allergic to numbers per se. As a political scientist, I have taken particular pleasure in encouraging my more empirically-oriented colleagues to cast their scholarship in terms that relate to enduring humanities texts and themes, and to express their ideas in language that transcends the merely technical or methodological.

All applicants, not just political scientists, should bear in mind that the Endowment will not fund "projects that advocate or promote a particular political, ideological, religious, or partisan point of view." This proscription does not require that political scientists feign value neutrality when they seek funding from NEH. It does mean that projects must not be tendentious. Applicants whose projects have direct implications for public policy need to take special pains to show that they aim to advance learning, rather than 
merely raise consciousness.

Political scientists should understand that their proposals will not necessarily be reviewed by scholars in their own discipline, let alone in their particular area of sub-disciplinary expertise. In general, the "disciplinariness" of the review will be determined by the number of proposals that a grant program receives at a particular deadline. For example, in a high-volume program such as Summer Stipends, it is easy (because the number of applications is sufficiently large) to justify convening a separate panel to review proposals in a particular discipline. Where the number of applications is more modest, several categories will sometimes be collapsed, resulting in hybrid panels (e.g., political science, jurisprudence, and economics). Sometimes political science applications are reviewed with history proposals. In the Division of Education Programs, which receives a fairly small number of applications, many of which (e.g., a proposal to reform the honors program at a small liberal arts college, or a proposal for a summer institute for school teachers on the Italian Renaissance) are intrinsically interdisciplinary, applications always receive a generalist review. Supplemental review by specialists is sought when needed, but there is no guarantee that a political scientist's proposal to the Education division will be read by even one colleague in the field. This need not be a disadvantage so long as applicants understand that they should cast their projects in terms that colleagues in other disciplines can understand.

In many of the Endowment's funding programs-the low-volume programs, by and large-members of the Endowment's professional staff become deeply involved in the development of applications. In those programs that offer such services staff members are charged with helping applicants make their proposals as competitive as possible. Every review process has its vagaries, of course, and staff approbation is no guarantee of success. But our records indicate that those applications receiving extensive staff work are more likely to be funded. Pertinent here is the testimony of Kathleen B. Jones, San Diego State University, who has offered two NEH summer seminars for school teachers on "Authority, Democracy, and the Citizenship of Women":

In my own experience, submitting a preliminary proposal and having an experienced member of the staff review it makes all the difference between a successful proposal and one that will be disregarded. When I initially submitted my 1988 summer seminar proposal I was told that I had the germ of a good idea, but that it was inappropriately presented. The criticisms offered were extensive, precise, encouraging and supportive. I went through at least two more revisions (also reviewed), and then submitted a final proposal. This process, which few are aware of or exploit, should be emphasized.

\section{III. Recent NEH Support for Women and Politics Research}

Projects on the general topic of women and politics are eligible in all of the Endowment's divisions. The purpose of the project and the audience to which it appeals will determine the program in which to make application.

Whether it receives a disciplinary review or a generalist review, a proposal on women and politics will be read against program criteria, which will vary according to the nature of the project (a conference, a seminar, a curriculum project, a film, a translation, or whatever), but panelists will in any event ask whether the project is likely to yield a significant contribution to learning in the humanities. Because it will be competing with worthy proposals from other disciplines, a women and politics proposal will have to appear every bit as central to the humanities as projects on, say, Buddhism or Plutarch or Emily Dickenson. There is no reason, of course, why this should pose a problem. But it is an argument for explicitness. Do not assume that reviewers will automatically concede the importance of your topic for learning in the humanities.

Scholars working in the field will be heartened to know that the Endowment has made a substantial investment in women and politics scholarship. The titles listed below, drawn from several divisions of the $\mathrm{NEH}$, reflect the range and breadth of projects undertaken in this area. All grants listed were made in fiscal 1988 or 1989.

\section{Fellowships for University Teachers}

Grants provide support for members of the faculty of Ph.D.-granting universities to undertake full-time independent study and research in the humanities.

Rachel G. Fuchs, Arizona State University, "Charity and Welfare for Mothers in 19th-Century Paris."

Joan G. Zimmerman, Howard University, "Instrumentalism versus Conceptualism in Drafting the Equal Rights Amendments, 1905-23."

\section{Fellowships for College Teachers and Independent Scholars}

Grants provide support for teachers in two-year, four-year, and five-year colleges and universities that do not grant the Ph.D., and also for independent scholars and writers, to undertake full-time independent study and research in the humanities.

Robert C. Bannister, Swarthmore College, "Women and the Social Sciences in America, 1920-60."

Dolores E. Janiewski, Mount Holyoke College, "The Politics of Suffrage in the New South."

Mary Kelley, Dartmouth College, “Achieving Authority: Women's

Entrance into Public Life in Early America."

Carol Farley Kessler, Pennsylvania

State University, Delaware

Campus, "New Lives, New

Worlds: Utopian Novels by

American Women, 1836 to the Present."

Alice S. Klak, Eastern Oregon State College, "Graphics of the Women's Suffrage Campaign."

Cheryl E. Martin, University of Texas at El Paso, "Popular Attitudes and Ideology in Northern Mexico, 1650-1850."

Elaine M. Smith, Alabama State University, "A Biography of 
Mary McLeod Bethune."

Margaret Ann Strobel, University of Illinois, Chicago, "Socialist Feminism and Women's Unions in the 1970s."

\section{Summer Stipends}

Grants in this category provide support for college and university teachers and others to undertake fulltime independent study and research in the humanities for two consecutive summer months. College and university teachers must be nominated by their institutions.

Lisa E. Emmerich, Kenyon College, "Promoting Civilized Motherhood: The Case of the 'Save the Babies' Campaign."

James Henderson, Valparaiso University, "Equal Pay to Men and Women for Equal Work: The Early Debate, 1891-1923."

Mark E. Kann, University of Southern California, "The Other Liberal Tradition in Early America: Civic Virtue and Gender."

Susan E. Marshall, University of Texas, Austin, "The American Antisuffrage Movement, 1890-1930."

Thomas A. J. McGinn, Vanderbilt University, "Prostitution and the Law: The Formation of Social Policy in Early Imperial Rome."

Robyn L. Muncy, Le Moyne College, "Female Reformers and Policymakers in the Progressive Era, 1890-1930."

Kristen B. Neuschel, Duke University, "Gender Roles in the French Aristocracy, 1550-1650."

Carolyn J. Stefanco, Wheaton College, "Divided Loyalties: Nelly Kinzie Gordon's Civil War."

\section{Travel to Collections}

These $\$ 750$ grants help defray travel costs, thereby enabling scholars to study humanities materials in libraries, archives, museums, or other repositories.

Nancy Fix Anderson, Loyola University, New Orleans, "Annie Besant and the Status of Women in India: Anti-Imperialism versus
Human Rights."

Terry D. Bilhartz, Sam Houston State University, "Anna Howard Shaw and the Crusade for Women's Rights."

Janet Farrell Brodie, California State Polytechnic University, "Women and Freethought in the United States, 1820-1860."

Dorothy Sue Cobble, Rutgers University, "Waitresses: Their Work, Culture, and Unions in the Twentieth Century."

Susan P. Conner, Central Michigan University, "Poverty and Marginality: The Role of Prostitution in French Revolutionary Social Control."

Esther S. Cope, University of Nebraska, "A Woman Prophet's Critique of English Politics and Religion."

RaGena C. DeAragon, Gonzaga University, "Aristocratic Widows and the English Crown, 1066-1215."

Suzanne K. Engler, University of Southern California, "Power and Dependence: The Women of Flowerdew Hundred Plantation."

J. Wayne Flynt, Auburn University, "Pattie R. Jacobs, Woman Suffrage, and Southern Sectionalism."

Diana Greene, Alliance of Independent Scholars, "Karolina Pavlova and the Position of Women in the 1840s."

Lisbeth M. Haas, University of California, Santa Cruz, "Gender and Political Identity in the Barrios of Southwest, 18601940."

June E. Hahner, SUNY at Albany, "Women's Rights and Politics in Brazil, 1850-1940."

Claire Hirshfield, Pennsylvania State University, Ogontz Campus, "Women's Political Auxiliaries in Late Victorian and Edwardian England."

Carolyn C. Jones, Saint Louis University, "The Price of Citizenship: Women and Federal Taxation in 20th-Century America."
Susan Lynn, University of Missouri, Saint Louis, "Women and Progressive Politics, 1945-65."

Martha H. Swain, Texas Woman's University, "Ellen S. Woodward: Southern Gentlewoman and New Deal Official."

Gayle T. Tate, Indiana University, "The Kin Keepers: Political Philosophies of African-American Women."

Carolyn E. Wedin, University of Wisconsin, Whitewater, "Mary White Ovington, Cofounder of the National Association for the Advancement of Colored People."

\section{Younger Scholars}

Grants provide support for high school and college students to conduct research and writing projects in the humanities for nine weeks during the summer under the supervision of a humanities scholar.

Sarah K. Flotten, Kenyon College, "The Women's Suffrage Movement in Minnesota, 1894-1923."

Mark W. Sabel, Swarthmore College, "The Southern White Woman as Activist in the Black Civil Rights Movement."

Brande M. Stellings, Yale University, "Republican Ideology and the Language of Early 19thCentury Working Women's Protests."

Joan D. Wellman, University of Kansas, "A Feminist Critique of Plato's Republic."

\section{Summer Seminars for College Teachers}

Grants provide support for scholars of the humanities to direct summer seminars at institutions with collections suitable for advanced study.

Karen Offen, Stanford University, "The Woman Question in an Age of Revolutions: Europe and America, 1750-1880."

\section{Summer Seminars for School Teachers}

Grants provide support for accomplished teachers and scholars to 
direct summer seminars at colleges, universities, museums, libraries, and similar institutions. Seminars are usually organized around a close reading of significant humanities texts.

Kathleen B. Jones, San Diego

State University, "Authority, Democracy, and the Citizenship of Women: Hobbes, Locke, Rousseau, and Wollstonecraft."

Elisabeth I. Perry, Vanderbilt University, "Feminist Classics in American Culture, 1850-1930."

\section{Research Editions}

Grants support various stages in the preparation of authoritative and annotated editions of works and documents of value to humanities scholars and general readers.

Arlie R. Hochschild, University of California, Berkeley, "The Emma Goldman Papers."

Patricia G. Holland, University of Massachusetts, Amherst, "The Papers of Elizabeth Cady Stanton and Susan B. Anthony."

\section{Research Conferences}

Grants support conferences designed to advance the state of research in a field or topic of major importance in the humanities.

Noralee Frankel, American Historical Association, "Conference on Women in the Progressive Era, 1890-1925."

\section{Humanities Projects in Libraries and Archives}

Grants assist museums, historical organizations, and other similar cultural institutions in the planning and implementation of interpretive programs that use cultural and artistic artifacts to convey and interpret the humanities to the general public.

Eileen Dubin, Stockton State College, "Women, War, and Peace: The American Experience in the 20th Century."

Barbara Matz, West Virginia
Women's Federation, "West Virginia Women's Cultural History Project."

Diantha Schull, The New York Public Library, "Women as a Force in United States History."

\section{Public Humanities Projects}

Grants support projects designed to increase public understanding of the humanities. Through this program, the Endowment recognizes exemplary public programs and promotes model humanities projects of potential national significance. Project formats may include public symposia, community fora, debates, interpretive pamphlets, or audiovisual materials.

Robert Maniquis, University of California, Los Angeles, "Humanities Program for the Bicentennial of the French Revolution."

Donald M. Rogers, University of Hartford, "Extension of the Right to Vote."

Gene Ruoff, University of Illinois at Chicago, "Jane Addams' HullHouse: Humanities Programs for the Centennial.

\section{Elementary and Secondary Education in the Humanities}

Cathryn Adamsky, University of New Hampshire, "Women in Nineteenth-Century American Culture."

\section{IV. Conclusion}

NEH reviewers do not take it for granted that the research interests of political scientists lie at the heart of the heart of the humanities. They must be persuaded. But political scientists focusing on questions of enduring interest to humanities scholars-questions about the meaning of justice, the tension between liberty and equality, the requirements of citizenship, the political status of women, etc.-will find that they are preaching to the choir. Such projects, and those that adopt an essentially historical approach to their subjects, will continue to attract support from the Endowment.

Without doubt, future funding patterns will also reflect changing scholarly interests and the development of new topics, conceptual frameworks, and methods of analysis. As the project titles listed and referred to in this essay reveal, the humanities are vital and capaciouscapacious enough to extend from Plato to NATO (or perhaps, given my topic, from doting to voting, or from Becky Thatcher to Margaret Thatcher). We invite you to discuss your ideas with us.

\section{V. NEH Directory}
Division of Education Programs, Room $302 \quad 202 / 786-0373$
Division of Fellowships and Seminars, Room 316 202/786-0458
Division of General Programs, Room 426 202/786-0267
Division of Research Programs, Room 318 202/786-0200
Division of State Programs, Room $411 \quad 202 / 786-0254$
Office of Challenge Grants, Room 429 202/786-0361
Office of Preservation, Room 802 202/786-0570
Office of Public Affairs,
Room 406 202/786-0438

National Endowment for the Humanities

1100 Pennsylvania Avenue, N.W. Washington, DC 20506

\section{Notes}

*This manuscript was originally prepared for delivery at the meeting of the APSA Committee on the Status of Women Roundtable in Atlanta, Georgia, September 1, 1989.

**This section consists of prose liberally appropriated from Overview of Endowment Programs, a general information booklet prepared by the NEH Office of Publications and Public Affairs. 